\title{
Explanation of Academic Achievement Based on Personality Characteristics Psycho-Social Climate of the Classroom and Students' Academic Engagement in Mathematics
}

\author{
Khadijeh Abolmaali ${ }^{*}$, Masoumeh Rashedi², Bita Ajilchi ${ }^{3}$ \\ ${ }^{1}$ Department of Psychology, Roudehen Branch, Islamic Azad University, Roudehen, Iran \\ ${ }^{2}$ Department of Psychology, Saveh Branch, Islamic Azad University, Saveh, Iran \\ ${ }^{3}$ Department of Psychology, Faculty of Human Science, Science and Research Branch University, Islamic Azad \\ University (IAU), Tehran, Iran \\ Email: ${ }^{\text {sama.abolmaali@gmail.com }}$
}

Received 17 February 2014; revised 20 March 2014; accepted 29 March 2014

Copyright (C) 2014 by authors and Scientific Research Publishing Inc.

This work is licensed under the Creative Commons Attribution International License (CC BY). http://creativecommons.org/licenses/by/4.0/

\section{(c) (i)

\begin{abstract}
This research explains academic achievement based on the personality characteristics, the psycho-social climate of the classroom in terms of academic engagement in mathematics. The population was high schoolboys and girls in Damghan city in Iran. Participants were randomly selected using a multi-stage cluster method (513 boys and girls) and they simultaneously completed three questionnaires: academic engagement, the psycho-social climate of the classroom and personality characteristics. Path analysis was used to analyze data. The results showed that the direct effects of personality characteristics and psycho-social climate of the classroom on academic achievement were not significant. The direct effects of openness, conscientiousness and psycho-social climate of classroom on academic engagement were significant. The indirect effects (with mediation of academic engagement) and overall effects of openness, conscientiousness and psycho-social climate of classroom on academic achievement were significant, also the effect of academic engagement on academic achievement was significant.
\end{abstract}

\section{Keywords}

Academic Achievement, Personality Characteristics, Psychosocial Climate of Classroom (PSCC),

"Corresponding author.

How to cite this paper: Abolmaali, Kh., et al. (2014) Explanation of Academic Achievement Based on Personality Characteristics Psycho-Social Climate of the Classroom and Students' Academic Engagement in Mathematics. Open Journal of Applied Sciences, 4, 225-233. http://dx.doi.org/10.4236/ojapps.2014.45022 


\section{Student's Mathematical Academic Engagement}

\section{Introduction}

Academic achievement is considered as a criterion by which to decide on the effectiveness of educational programmes. Researchers evaluating an education system often take notice of academic achievement and look for factors that affect academic achievement. They have identified various factors including: 1) Cognitive factors such as intelligence [1], the way of information processing, and the use of cognitive and meta cognitive strategies [2], styles of thinking and learning [2] [3] and creativity [4]; 2) Motivational factors such as goal orientation and motivational beliefs [5]-[7], and internal and external motivation [8]; 3) Factors related to the quality of instruction in schools such as teaching methods and the psycho-social climate of the classroom [9] [10], the structure of the classroom [11], the feeling of belonging to the school [12] and perceptions of classroom environment [13] [14]; 4) Family factors such as family environment perception [12], family support perception [15]; 5) Socio-economic status such as parent's education and their occupation [16]; 6) Non-cognitive factors such as personality traits [17] [18], identity styles [16], self-concept and self-esteem [19]; and 7) A combination of different factors (cognitive, emotional, behavioral) such as academic engagement [20]-[22], and resiliency [10].

Although, the results of the above-mentioned research are different in some areas, these variables have been taken note of by educators. In this research the relationship between the psycho-social climate of classroom (PSCC), personality characteristics and academic engagement with academic achievement has been studied.

In general, academic engagement leads to more effort and participation in academic activities and the promotion of educational outcomes. Linnenbrink and Pintrich [23] showed that academic engagement is a multidimensional structure that has three components: behavioral, cognitive and emotional. Some of specialists suggest that when homework has value for students, they become involved in it [20]. In this study considering the importance of engagement in mathematics has been studied. Based on results of the TIMMS study in 2003, Iran ranked 24th among the 25 countries that participated in an assessment of fourth grade elementary mathematics [24].

Behavioral engagement is considered as a variety of observable behavior in terms of exposure to homework and of maintaining student's efforts with regard to academic activity, and because they seek help from others when doing homework and participating in class [25]. Researchers suggest that behavioral engagement has a positive impact on academic achievement [26].

Cognitive involvement consists of a variety of information processing approaches that students use for learning. The degree of cognitive engagement has been investigated as a mediator variable that impacts on learning strategies (meta cognitive and cognitive strategies such as deep processing, meaning elaboration and the organization of information). The relationship between learning and academic achievement in high school students is mediated by cognitive engagement [27] [28]. Elliott, McGregor and Gable [29] explained that deep cognitive engagement is positively related to academic performance, but there is no relationship between academic performance and surface cognitive engagement. The results of Wolters' research [30] showed when successful high school students do math homework, they use more cognitive strategies. Some researchers have reported a positive relationship between learning strategies (cognitive and Meta cognitive) and academic achievement [2] [6] [7].

The affective dimension of academic engagement consists of individual variables (internal variables that are related to the self) and contextual variables (such as peer relationships, classroom climate and family support). These variables could explain academic achievement [31]-[34].

The psycho-social climate of the classroom (PSCC) is considered as a contextual variable that impacts on affective outcomes and the academic behavior of students, and reflects on the interpersonal relationships between student/teacher and student/student, and explains students' expectations and perceptions. PSCC has two dimensions: perception and expectation. It is recognized there is a significant positive relationship between PSCC and academic progress [35] [36]. Hojat-Ansari stated that optimal PSCC could lead to positive and purposeful relationships between teachers and students [37]. Bianfar concluded that the perception and expectation of a positive PSCC leads to academic progress [38].

Personality is also an important factor that motivates learning and has an influence on the academic perfor- 
mance of students. Personality is a relatively continuous trait and has tendencies or characteristics that ensure the stability of behavior in individuals [39]. The so-called Big Five personality traits are neuroticism, extroversion, openness, agreeableness and conscientiousness. Neurotic people are described as having traits such as shyness, high levels of anxiety and an unstable temperament. Extroverts are social and self-assertive individuals who are optimistic in terms of life experience. Open people are described as being open-minded, with an active imagination and independent judgment. They seek variety in their lives. They are very curious about their surroundings and constantly seeking to gain new experiences. Agreeable people tend to emphasize the need for trust and patience, and respect laws and the beliefs of others. Conscientious people have a high sense of responsibility and accountability and tend to progress and focus on the task and their work [40]. Recent studies have shown that conscientiousness could be a strong predictor of academic achievement [17] [41] [42] and this prediction also includes performance in tests [43]. According to what has been said above, it is necessary for creating a bridge between the individual and social areas. Individual areas include personality characteristics, engagement in school activities and homework and so on, while social areas include the environment of the classroom such as PSCC.

So, in this study, we have tried to answer the question as to whether or not the academic achievement of students could be predicted based on personality characteristics and PSCC, with the mediation of academic engagement in mathematics. To answer this question, the conceptual model used in this study was fitted with data collected from a statistical sample. Theoretical model is given in Figure 1.

\section{Method}

\subsection{Procedure}

The method adopted by this research was quantitative in nature. The research population included both boys and girls who were educated in the high schools of Damghan city in Iran. Following Schumacker and Lomax’s suggestion, the participant ratio to the estimated parameters was considered to be 1:20 and the total number was estimated at 420, which increased to 550 with we considered pre-estimation [44]. Due to the failure to complete 37 questionnaires (the measuring tool), the sample volume was reduced to 513 participants (i.e. 310 girls and 203 boys).

Objective: Identification of the effects of personality characteristics and PSCC on academic achievement with the mediation of academic engagement.

Research assumptions:

1) PSCC and personality characteristics have direct effects on academic achievement.

2) PSCC and personality characteristics have indirect effects on academic achievement that are mediated by academic engagement.

3) PSCC and personality characteristics have direct effects on academic engagement.

For data collection, three questionnaires are used:

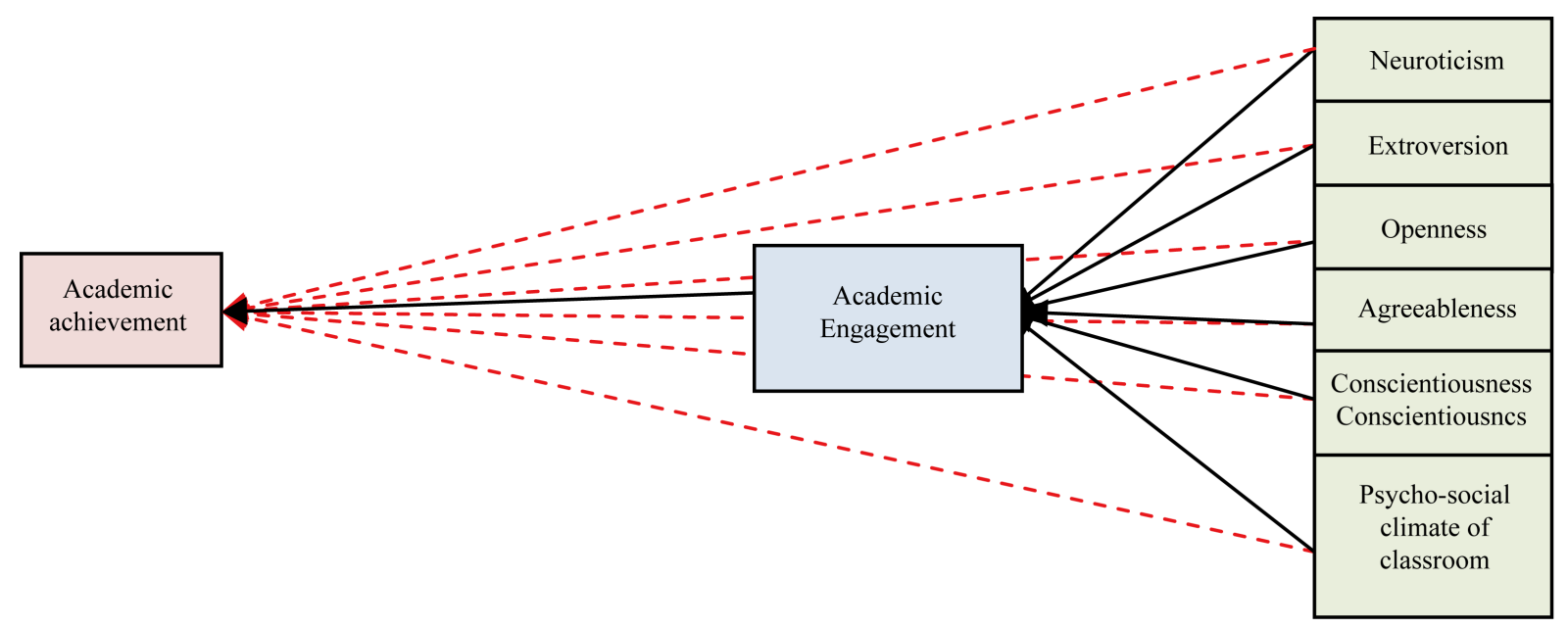




\subsection{Instruments}

\subsubsection{Academic Engagement Questionnaire}

This questionnaire has 32 questions that measure the behavioral, emotional and cognitive aspects of academic engagement. It is one of the subscales of the motivation strategies for learning questionnaire (MSLQ), which was produced by Pintrich in 1994 [45]. In Iran, Abedini reported on the reliability of this test in terms of internal consistency and Chronbach alpha coefficients [21]. These were reported for behavioral dimensions (effort), emotional (the task), cognitive strategies and Meta cognitive strategies as 0.69, 0.90, 0.69 and 0.75 respectively. In the present study, the reliability of this test in terms of internal consistency was obtained in line with the above order as $0.59,0.66,0.59$ and 0.73 respectively.

\subsubsection{Psychosocial Climate of the Classroom}

The PSCC questionnaire is used for measuring the Psycho-Social Climate of Classroom as proposed in 1990 by Michaud, Comeau and Goupil [46]. PSCC assesses 2 dimensions: perception and expectation. In this research, only the dimension of perception was assessed. The internal consistency reliability of this test in Iran in terms of the dimension of perception was about 0.68 [37], and specialists have emphasized its content validity.

\subsubsection{Personality Questionnaire-Short Form (NEO-FFI)}

This questionnaire assesses the personality characteristics of neuroticism, extraversion, openness, agreeableness and conscientiousness. Cronbach's alpha coefficient in terms of neuroticism to openness was measured by Costa \& McCrae in 1992 at between 0.68 and 0.86 [47]. In Iran, GaroosiFarshi obtained Cronbach's alpha coefficients of $0.84,0.75,0.74,0.75$ and 0.83 respectively [48]. In the present study, Cronbach's alpha coefficients in terms of the above dimensions were measured at $0.678,0.594,0.531,0.509$, and 0.738 , respectively.

In order to comply with ethical standards, the following points were considered:

Obtaining permission from the educational organizations in Domghan city, and school administrators; obtaining informed consent of participants; and Reassure participants that the information collected will remain confidential.

\section{Results}

According to the Table 1, the standard deviation of PSSS is more than the standard deviation of the other variables. Kurtosis and skewness show that the distribution of the data is almost normal. Fifty three percent of the participants were female and $47 \%$ were male, and $54 \%$ in math field and $46 \%$ in science field studied and their mean age was 17 years.

To test the hypothesis, path analysis was used. The direct, indirect and overall effects of the path coefficients are reported in Table 2. The St.d., $t$ and $\mathrm{R}^{2}$, with and without indirect effects, were reported.

Table 2 showed that:

Table 1. Descriptive indices of under-study variables.

\begin{tabular}{|c|c|c|c|c|c|c|c|}
\hline \multicolumn{8}{|c|}{ Descriptive indices } \\
\hline selbairav & naem & $\begin{array}{c}\text { standard } \\
\text { deviation }\end{array}$ & ecnairav & ssenweks & $\begin{array}{c}\text { St.d of } \\
\text { skewness }\end{array}$ & sisotruk & $\begin{array}{c}\text { St.d of } \\
\text { skewness }\end{array}$ \\
\hline academic achievement & 17.51 & 1.79 & 3.21 & -1.00 & 0.108 & 0.654 & 0.215 \\
\hline academic engagement & 107.88 & 13.46 & 181.18 & -0.48 & 0.108 & 0.270 & 0.215 \\
\hline neuroticism & 17.25 & 5.82 & 33.90 & -0.13 & 0.108 & -0.422 & 0.216 \\
\hline extraversion & 22.04 & 4.86 & 23.45 & -0.36 & 0.108 & 0.105 & 0.215 \\
\hline openness & 11.35 & 2.83 & 7.99 & -0.655 & 0.108 & 0.553 & 0.215 \\
\hline agreeableness & 12.06 & 4.22 & 17.80 & -0.135 & 0.108 & 0.059 & 0.216 \\
\hline conscientiousness & 33.84 & 6.99 & 48.80 & -0.466 & 0.108 & -0.163 & 0.215 \\
\hline CCSP & 15.22 & 2.64 & 6.98 & -0.544 & 0.108 & 0.359 & 0.215 \\
\hline
\end{tabular}


Table 2. The finding of path analysis.

\begin{tabular}{|c|c|c|c|c|c|c|c|c|c|c|c|c|}
\hline \multicolumn{13}{|c|}{ Direct, Indirect and Overall path coefficients, St.d, t, $\mathrm{R}^{2}$ with and without direct effect } \\
\hline & $\begin{array}{l}\text { Nonstandardized } \\
\text { path coefficients } \\
\text { (direct effect) }\end{array}$ & $\begin{array}{l}\text { St.d of } \\
\text { direct } \\
\text { effect }\end{array}$ & $\mathrm{t}$ & $\begin{array}{l}\text { Nonstandardized } \\
\text { path coefficients } \\
\text { (direct effect) }\end{array}$ & $\begin{array}{l}\text { Indirect } \\
\text { effects }\end{array}$ & $\begin{array}{c}\text { St.d of } \\
\text { indirect } \\
\text { effect }\end{array}$ & $\mathrm{t}$ & $\begin{array}{l}\text { overall } \\
\text { effects }\end{array}$ & $\begin{array}{c}\text { St.d of } \\
\text { overall } \\
\text { effect }\end{array}$ & $\mathrm{t}$ & $\mathrm{R}^{2}$ & $\begin{array}{c}\mathrm{R}^{2} \text { with and } \\
\text { without } \\
\text { indirect } \\
\text { effects }\end{array}$ \\
\hline $\begin{array}{l}\text { The effect of } \\
\text { engagement on } \\
\text { achievement }\end{array}$ & 0.03 & 0.01 & 5.04 & 0.24 & - & - & - & 0.03 & 0.01 & 5.04 & 0.20 & \\
\hline $\begin{array}{l}\text { The effect of } \\
\text { neuroticism on } \\
\text { engagement }\end{array}$ & 0.000 & 0.10 & -0.03 & 0.000 & - & - & - & 0.000 & 0.10 & -0.03 & & \\
\hline $\begin{array}{l}\text { The effect of } \\
\text { extroversion on } \\
\text { engagement }\end{array}$ & 0.09 & 0.12 & 0.76 & 0.03 & - & - & - & 0.09 & 0.12 & 0.76 & & \\
\hline $\begin{array}{l}\text { The effect of } \\
\text { openness on } \\
\text { engagement }\end{array}$ & 0.57 & 0.20 & 2.87 & 0.12 & - & - & - & 0.57 & 0.20 & 2.87 & & \\
\hline $\begin{array}{l}\text { The effect of } \\
\text { agreeableness on } \\
\text { engagement }\end{array}$ & 0.21 & 0.14 & 1.49 & 0.06 & - & - & - & 0.21 & 0.14 & 1.49 & & \\
\hline $\begin{array}{l}\text { The effect of } \\
\text { conscientiousness } \\
\text { on engagement }\end{array}$ & 0.64 & 0.08 & 7.61 & 0.33 & - & - & - & 0.64 & 0.08 & 7.61 & & \\
\hline $\begin{array}{l}\text { The effect of } \\
\text { PSCC on } \\
\text { engagement }\end{array}$ & 0.70 & 0.21 & 3.38 & 0.14 & - & - & - & 0.70 & 0.21 & 3.38 & & \\
\hline $\begin{array}{l}\text { The effect of } \\
\text { neuroticism on } \\
\text { achievement }\end{array}$ & -0.03 & 0.01 & -1.85 & -0.09 & 0.000 & 0.000 & -0.03 & -0.03 & 0.01 & -1.85 & -0.06 & 0.01 \\
\hline $\begin{array}{l}\text { The effect of } \\
\text { extroversion on } \\
\text { achievement }\end{array}$ & -0.02 & 0.02 & -0.96 & -0.04 & 0.000 & 0.000 & 0.76 & -0.01 & 0.02 & -0.77 & & \\
\hline $\begin{array}{l}\text { The effect of } \\
\text { openness on } \\
\text { achievement }\end{array}$ & 0.01 & 0.03 & 0.48 & 0.02 & 0.02 & 0.01 & 2.49 & 0.03 & 0.03 & 1.10 & & \\
\hline $\begin{array}{l}\text { The effect of } \\
\text { agreeableness on } \\
\text { achievement }\end{array}$ & 0.000 & 0.02 & -0.22 & -0.01 & 0.01 & 0.000 & 1.43 & 0.000 & 0.02 & 0.11 & & \\
\hline $\begin{array}{l}\text { The effect of } \\
\text { conscientiousness } \\
\text { on achievement }\end{array}$ & -0.01 & 0.01 & -0.93 & -0.05 & 0.02 & 0.000 & 4.20 & 0.01 & 0.01 & 0.71 & & \\
\hline $\begin{array}{l}\text { The effect of } \\
\text { PSCC on } \\
\text { achievement }\end{array}$ & 0.04 & 0.03 & 1.18 & -0.05 & 0.02 & 0.01 & 2.81 & 0.07 & 0.03 & 2 & & \\
\hline
\end{tabular}

1) The direct effects of personality characteristics and PSCC on academic achievement are not significant.

2) The direct effect of academic engagement with regard to mathematics on academic achievement is significant.

3) The direct effect of PSCC and openness and conscientiousness on academic engagement in mathematics is significant.

4) The overall and indirect effects of openness, conscientiousness and PSCC on academic achievement with mediation of academic engagement are significant. Therefore the role of mediator in terms of academic engagement is confirmed.

5) The direct effect of PSCC on academic engagement is significant. 
In this model, $20 \%$ of the total variance of academic engagement and $6.7 \%$ of the variance of academic achievement is explained. The fitted model is given in Figure 2.

\section{Discussion}

In this study, the results show that the direct effect of academic engagement in mathematics on academic achievement is significant. These results are in good agreement with those of other researchers [5] [49]-[52].

In this research, the direct effect of PSCC on academic engagement was found to be significant and positive. These results are consistent with the findings of Atofi-Salmani et al. and Keramati [36] [53]. Also, according to the results obtained in this research, the overall effect of PSCC on academic achievement was significant, findings that are confirmed by the results of many researches [7] [53]-[55]. It seems that a good PSCC could create an optimal community in terms of friendship between the teacher/learner and learner/learner, and leads to students demonstrating an increased amount of academic engagement.

In this study, the direct effects of openness and conscientiousness on mathematics academic engagement were significant. These results are consistent with the findings of Duff, Boyle, Dunleavy and Ferguson [56], Dunsmore [57], Komarraju et al. [42] and Atashrouze et al. [17]. But in this study, neuroticism, extraversion and agreeableness could not directly predict mathematics academic engagement. Such findings were also obtained in Furnham, Zhang and Chamorro's research in 2006, and that of Duff et al. [56] [58]. Based on the findings of the present study, openness, conscientiousness and agreeableness have significant indirect effects on academic achievement. The findings were confirmed by the results obtained by Duff et al., Dunsmore; Furnham et al.; Furnham, Chamorro-Premuzic and McDougall; and Hakimi [18] [56]-[59]. It seems that conscientiousness leads to an interest in the course. Individuals with conscientiousness tend to carry out their duties carefully, and try to raise their own performance and ensure progress. High persistence and high achievement guarantee academic success. People that are open to new assignments also enjoy experiencing more academic engagement.

\section{Conclusion}

It seems that for building a positive psychosocial climate of the classroom needs to social-emotional learning (SES). SES is built upon caring relationship and warm but challenging classroom and school environment. These classrooms are places where students feel cared about, welcomed, valued and seen as more than just learnersthey are seen as resources (Elias, 2003). As a result a classroom with positive psychosocial climate could be challenging for students and can foster cognitive, affective and behavioral engagement in academic tasks and leads to academic achievement. The findings with regard to the importance of students' involvement and a safe PSCC classroom suggest teachers to build a safe environment for involving learners in learning activities, allowing them to increase their opportunities with regard to academic achievement. Furthermore, given the significant

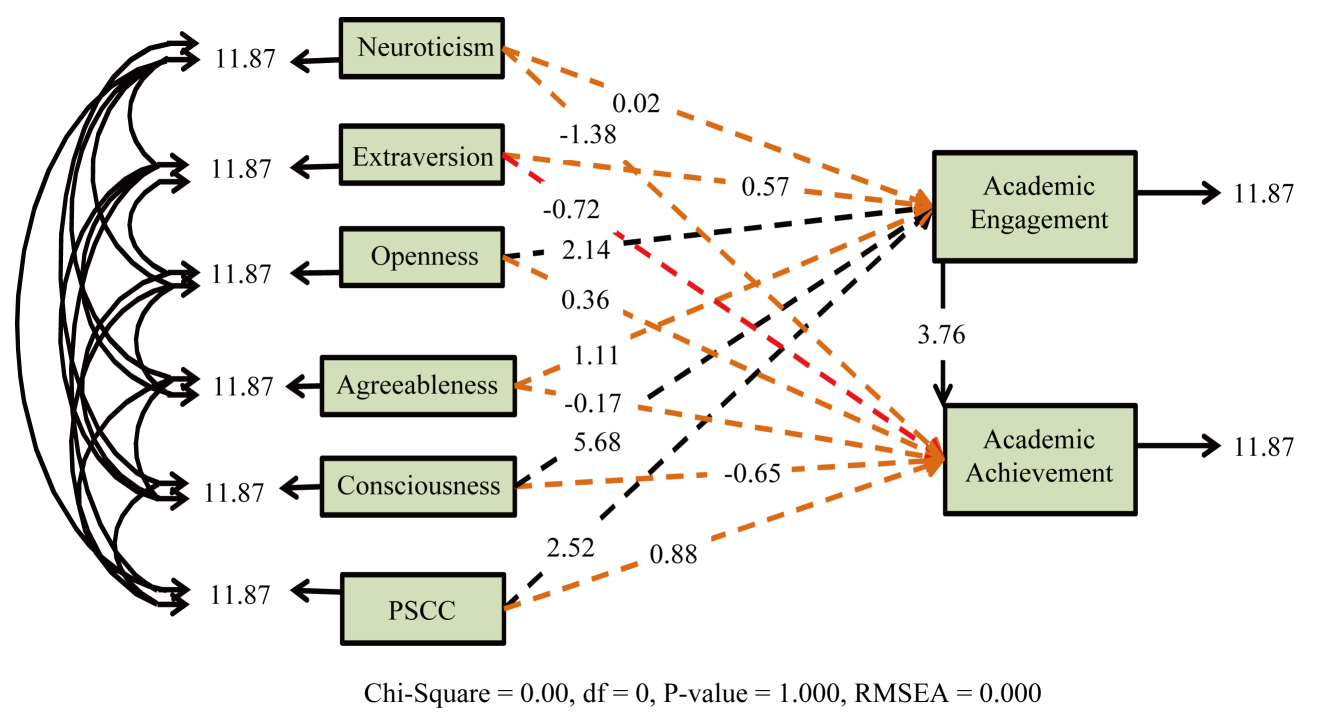

Figure 2. The fitted model, using path analysis. 
and positive contribution of conscientiousness and openness in explaining academic engagement, it is recommended that teachers use teaching methods based on experience action and use cooperative learning strategies to motivate and engage learners in academic task and strengthen sense of student's responsibility. In this research, importance of academic engagement in mathematics, as an intermediate variable, is emphasized. That academic engagement can role-play as a mediator that mediates the effects of personality traits on academic achievement. Therefore, it is recommended that teacher of mathematical lessons use strategies to engage their students in math.

\section{Acknowledgements}

We thank you from Damghan officials of education, school administrators, and all participants were provided the opportunity to conduct this research.

\section{References}

[1] Biabangard, A. (2006) The Relationship between Motivations of Achievement, Academic Achievement, in High School Students. MS Thesis, Allameh Tabatabaei University, Tehran. (in Persian)

[2] Abdollahpoor, M.A. (2004) The Relationship between Cognitive Style (Depending on Context, Independent of the Field), Learning Strategies (Cognitive and Meta Cognitive) and Students’ Academic Achievement in First Grade Boys. MS Thesis, Teacher Training University, Tehran. (in Persian)

[3] Hamrang, H. (2011) Predicting Academic Achievement of Students Based on Thinking Styles in Teachers. MS Thesis, Islamic Azad University, Roodehen. (in Persian)

[4] Rahnama, A. and Abdolmaleki, J. (2010) The Relationship between Emotional Intelligence and Creativity with Academic Achievement. Journal of New Thoughts Education, 5, 55-78. (in Persian)

[5] Hejazi, A., Rastegar, M., Krmdost, N. and Ghorban-Jahromi, R. (2009) Beliefs about Intelligence and Academic Achievement in Mathematics: The Role of Achievement Goals, Cognitive Engagement and Effort. Journal of Psychology and Education, 32, 46-25. (in Persian)

[6] Mousavinezhad, A. (1998) The Relationship between Motivational Beliefs and Self-Regulation and Academic Achievement Learning Strategies in Third-Year Students. MS Thesis, Tehran University, Tehran. (in Persian)

[7] Mohsenpour, B. (2004) The Role of Self-Efficacy, Achievement Goals, Learning Strategies and Sustainability on Achievement in Math and Science in High School Student in Tehran. MS Thesis, Tehran University, Tehran. (in Persian)

[8] Hassanzadeh, R. (2002) The Relationship between Motivation (Internal-External) Locus of Control (Internal-External) and Student's Academic Achievement. Journal of Human Science, Instructional Innovations, 2, 107-120. (in Persian)

[9] Bianfar, F. (2003) The Effect of Classroom Climate on Student's Academic Achievement in First Year High School Students of Tehran. MS Thesis, Islamic Azad University—Sciences and Research Branch of Tehran, Tehran. (in Persian)

[10] Zabihi, B., Newsha, B. and Mansouri, M. (2012) The Relationship between Resiliency and Psychosocial Climate of Classroom in High School Students in Tehran. New Thinking in Educational Science, 7, 3. (in Persian)

[11] Rostami, M. (2009) The Relationship between Genders, Structure of Classroom, Perceived Usefulness, Achievement Goals with Academic Achievement in English Language. MS Thesis, Tehran University, Tehran. (in Persian)

[12] Babakhani, N. (2012) A Model for Explanation of Self Regulation Based on Perception of Classroom and Family Environment, and Belongingness among High School Students in Tehran. Ph.D. Thesis, Islamic Azad University, Roudehen. (in Persian)

[13] Abolmaali, Kh., Hashemian, K. and Anary, F. (2012) Prediction of Perception of Environment of Classroom Based on Academic Engagement. New Thinking in Educational Science, 7, 19-33. (in Persian)

[14] Ahmadzadeh, M. (2009) The Relationship between Perception and Expectation of Psychological Climate of School with Academic Achievement. MS Thesis, Allameh Tabatabaei University, Tehran. (in Persian)

[15] Samadi, A. (2008) The Relationship between Perceived Support from Family, Teachers and Friends and Self-Efficacy with Academic Achievement among High School Students. MS Thesis, Allameh Tabatabaei University, Tehran. (in Persian)

[16] Saber, S. (2012) Explaining Academic Achievement Based on Socio-Economic Status, Identity Styles and Academic Engagement. Ph.D. Thesis, Islamic Azad University—Roudehen Branch, Roudehen. (in Persian)

[17] Atashrouze, B., Rastegar, N. and Askari, A. (2009) The Relationship between the Five Personality Characteristics and Academic Achievement. Iranian Journal of Psychology, 16, 376-367. (in Persian) 
[18] Hakimi, E. (2011) Personality Characteristics Related to Cognitive Styles and Academic Achievement of Students at Tehran University. MS Thesis, Tehran University, Tehran. (in Persian)

[19] Maarefat, A. and Ghazi, Gh. (2000) The Relationship between Self-Esteem and Academic Achievement of Secondary School Students in Shahre Rey. MS Thesis, Tehran University, Tehran. (in Persian)

[20] Schlechty, P.C. (2005) Creating Create Schools: Six Critical Systems at the Heart of Educational Innovation. John Wiley and Sons, San Francisco.

[21] Abedini, Y. (2008) The Role of Academic Engagement and Achievement Goals in Academic Achievement in Elementary Students. PhD Thesis, Tehran University, Tehran. (in Persian)

[22] Ryan, R.M. and Patrick, P.H. (2010) The Classroom Social Environment and Changes in Adolescents' Motivation and Engagement during Middle School. School Psychology International, 31, 312-328.

[23] Linnenbrink, E.A. and Pintrich, P.R. (2003) The Role of Self Efficacy Beliefs in Student Engagement and Learning in the Classroom. Reading and Writing Quarterly, 19, 119-137. http://dx.doi.org/10.1080/10573560308223

[24] Mohammad-Ismail, A. (2006) Report of the National Results of the Events and Outcomes of Mathematics Education in the TIMMS in 2003. National Center for International Study of TIMMS and Perls, Tehran. (in Persian)

[25] Finn, J.D. and Rock, D.A. (1997) Academic Success among Students at Risk for School Failure. Journal of Applied Psychology, 82, 221-234. http://dx.doi.org/10.1037/0021-9010.82.2.221

[26] Dupeyrat, C. and Marian, C. (2005) Implicit Theories of Intelligence, Goal Orientation, Cognitive Engagement \& Achievements: A Test of Dweck's Model with Returning to School Adults. Contemporary Educational Psychology, 30, 43-59. http://dx.doi.org/10.1016/j.cedpsych.2004.01.007

[27] Pintrich, P.R. and Garcia, T. (1991) Student Goal Orientation and Self-Regulation in the College Classroom. In: Maehr, M. and Pintrich, P., Eds., Advances in Motivation and Achievement, JAI, Greenwich, 271-402.

[28] Newman, F.M., Wehlage, G.G. and Lamborn, S.D. (1992) The Significance and Sources of Student Engagement. In: Newman, F.M., Ed., Student Engagement and Achievement in American Secondary Schools, Teachers College Press, New York, 11-39.

[29] Elliot, A., McGregor, H.A. and Gable, S. (1999) Achievement Goals, Study Strategies and Exam Performance: A Meditational Analysis. Journal of Educational Psychology, 91, 549-563.

[30] Wolters, C.A. (2004) Advancing Achievement Goal Theory: Using Goal, Structures and Goal Orientations to Predict Students' Motivation, Cognition and Achievement. Journal of Educational Psychology, 96, 236-250. http://dx.doi.org/10.1037/0022-0663.96.2.236

[31] Church, M.A., Elliot, A.J. and Gable, S.L. (2001) Perception of Classroom Environment, Achievement Goals Achievement Outcomes. Journal of Educational Psychology, 93, 43-54. http://dx.doi.org/10.1037/0022-0663.93.1.43

[32] Lee, D. and Young, T. (2001) Post-Traumatic Stress Disorder: Diagnostic Issues and Epidemiology in Adult Survivors of Traumatic Events. International Review of Psychiatry, 13, 150-158. http://dx.doi.org/10.1080/09540260120074000

[33] Larocque, M. (2008) Assessing Perceptions of the Environment in Elementary Classrooms: The Link with Achievement. Educational Psychology in Practices, 24, 289-305. http://dx.doi.org/10.1080/02667360802488732

[34] Sungur, S. and Gungoren, S. (2009) The Role of Classroom Environment Perceptions in Self-Regulated Learning and Science Achievement. Elementary Education Online, 8, 883-900.

[35] Mikaili, F. (1996) Students’ Perceptions from Psychology Environment of Classroom and Its Relationship to Academic Achievement, Intrinsic Motivation and Anxiety. MS Thesis, Tabriz University, Tabriz. (in Persian)

[36] Atofi-Salmani, M., Bahari, S. and GoodarziMalayeri, B. (2009) Effect of Psychosocial Climate Classroom on Academic Achievement among Fifth Grade Students in Kashan City. Journal of New Thinking in Educational Sciences, 4, 82-63. (In Persian)

[37] Hojat-Ansari, A.Z. (1996) The Effect of Psycho-Social Climate of Classroom in Academic Achievement. Journal of Psychology and Educational Sciences at Tehran University, 56, 117-138. (in Persian)

[38] Bianfar, F. (2003) The Effect of Classroom Climate on Student'S Academic Achievement in First Year High School Students of Tehran. MS Thesis, Islamic Azad University-Sciences and Research Branch of Tehran, Tehran. (in Persian)

[39] Feist, J. and Feist, G.J. (2002) Theories of Personality. 5th Edition, McGraw-Hill, Boston.

[40] Santrock, J. (2008) Educational Psychology. 3th Edition, McGraw-Hill, New York.

[41] Wagerman, S.A. and Funder, D.C. (2007) Acquaintance Reports of Personality and Academic Achievement: A Case for Conscientiousness. Journal of Research in Personality, 41, 221-229. http://dx.doi.org/10.1016/j.jrp.2006.03.001

[42] Komarraju, M., Karau, S.J. and Schmeck, R.R. (2009) Role of the Big Five Personality Traits in Predicting College Student’s Academic Motivation and Achievement. Learning and Individual Differences, 19, 47-52.

http://dx.doi.org/10.1016/j.lindif.2008.07.001 
[43] Chamorro-Premuzic, T. and Furnham, A. (2003) Personality Predicts Academic Performance: Evidence from Two Longitudinal University Samples. Journal of Research in Personality, 37, 319-338. http://dx.doi.org/10.1016/S0092-6566(02)00578-0

[44] Schumacker, R.E. and Lomax, R.G. (2004) A Beginner’s Guide to Structural Equation Modeling. Lawrence Erlbaum Associates, Mahwah, London.

[45] Pintrich, P.R. (1994) Continuities and Discontinuities: Future Directions for Research in Educational Psychology. Educational Psychologist, 29, 137-148. http://dx.doi.org/10.1207/s15326985ep2903_3

[46] Michaud, P., Comeau, M. and Goupil, G. (1990) The Learning Environment: Perceptions and Expectations of Students and Teachers. Canadian Journal of Education, 15, 57-71. (in French) http://dx.doi.org/10.2307/1495417

[47] Costa, P.T. and McCrae, R.R. (1992) NEO PI-R Professional Manual. Psychological Assessment Resources, Inc., Odessa.

[48] GaroosiFarshi, M. (1999) Standardization of a New Test and Analysis Features and Factor Structure of the NEO Personality among University Students in Iran. PhD Thesis, Tehran University, Tehran. (in Persian)

[49] Green, B.A., Miller, R.B., Crowson, H.M., Duke, B.L. and Akey, K.L. (2004) Predicting High School Students' Cognitive Engagement and Achievement: Contributions of Classroom Perceptions and Motivation. Contemporary Educational Psychology, 29, 462-482. http://dx.doi.org/10.1016/j.cedpsych.2004.01.006

[50] Reinek, W.M., Graway, K., Tucker, C.M. and Hall, C. (2003) Self-Efficacy, Goal Orientation and Fear of Failure as Predictors of School Engagement in High School Students. Psychology in Schools, 40, 417-424.

[51] Singh, K., Granvill, M. and Dika, S. (2002) Mathematics and Science Achievement: Effects of Motivation, Interest and Academic Engagement. Journal of Educational Research, 95, 323-332. http://dx.doi.org/10.1080/00220670209596607

[52] Tucker, C.M., Zayco, R.A., Herman, K.C., Reinke, W.M., Trujillo, M., Carraway, C. and Wallack, C. (2002) Teacher and Child Variables as Predictors of Academic Engagement among African American. Psychology in the Schools, 39, 477488. http://dx.doi.org/10.1002/pits.10038

[53] Keramati, M. (2006) Effects of Cooperative Learning on Social Skills and Academic Achievement in Math. Journal of Psychology and Educational Sciences, 7, 4-10. (in Persian)

[54] Bazargan, Z. (2007) Changes and Innovations in Schools. 1st Edition, The Association of Parents and Teachers, Tehran. (in Persian)

[55] Keramati, M. and Hosseini, B. (2007) Effects of Cooperative Learning on the Academic Achievement of Students in Physics. Tehran University, Journal of Psychology, 83, 166-147. (in Persian)

[56] Duff, A., Boyle, E., Dunleavy, K. and Ferguson, J. (2004) The Relationship between Personalities, Approach to Learning and Academic Performance. Personality and Individual Differences, 36, 1907-1920. http://dx.doi.org/10.1016/j.paid.2003.08.020

[57] Dunsmore, J.A. (2005) An Investigation of the Predictive Validity of Board and Narrow Personality Traits in Relation to Academic Achievement. University of Tennessee, Knoxille.

[58] Furnham, A., Zhang, J. and Chamoro, T. (2006) The Relationship between Psychometric and Self-Estimated Intelligence, Creativity, Personality and Academic Achievement. Imagination, Cognition and Personality, 25, 119-145. http://dx.doi.org/10.2190/530V-3M9U-7UQ8-FMBG

[59] Furnham, A., Chamorro-Premuzic, T. and McDougall, F. (2003) Personality, Cognitive Ability and Beliefs about Intelligence as Predictors of Academic Performance. Learning and Individual Differences, 14, 47-64. http://dx.doi.org/10.1016/j.lindif.2003.08.002 